\title{
Article
}

\section{The Effect of Clothing on the Rate of Decomposition and Diptera Colonization onsus scrofaCarcasses}

Card, Allison, Cross, Peter, Moffatt, Colin and Simmons, Tal

Available at http://clok.uclan.ac.uk/17823/

Card, Allison, Cross, Peter, Moffatt, Colin and Simmons, Tal (2015) The Effect of Clothing on the Rate of Decomposition and Diptera Colonization onSus scrofaCarcasses. Journal of Forensic Sciences, 60 (4). pp. 979-982. ISSN 00220-1198

It is advisable to refer to the publisher's version if you intend to cite from the work. http://dx.doi.org/10.1111/1556-4029.12750

For more information about UCLan's research in this area go to http://www.uclan.ac.uk/researchgroups/ and search for <name of research Group>.

For information about Research generally at UCLan please go to http://www.uclan.ac.uk/research/

All outputs in CLoK are protected by Intellectual Property Rights law, including Copyright law. Copyright, IPR and Moral Rights for the works on this site are retained by the individual authors and/or other copyright owners. Terms and conditions for use of this material are defined in the policies page.

\section{CLoK}

Central Lancashire online Knowledge www.clok.uclan.ac.uk

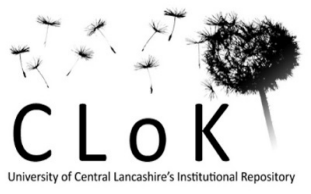


The Effect of Clothing on the Rate of Decomposition and Diptera Colonization on Sus scrofa Carcasses

Allison Card, MSc. ${ }^{1}$, Peter Cross, MSc. ${ }^{1}$, Colin Moffatt, $\mathrm{PhD}^{1}$ and Tal Simmons, $\mathrm{PhD}^{1}$

(1) School of Forensic and Investigative Sciences

University of Central Lancashire

Preston

PR1 2HE

UK 


\section{Abstract}

Twenty Sus scrofa carcasses were used to study the effect the presence clothing had on decomposition rate and colonization locations of Diptera species; 10 unclothed control carcasses were compared to 10 clothed experimental carcasses over 58 days. Data collection occurred at regular accumulated degree day intervals; the level of decomposition as Total Body Score (TBS surf $_{\text {), }}$ pattern of decomposition and Diptera present were documented. Results indicated a statistically significant difference in the rate of decomposition, $\left(t_{427}=2.59, p=0.010\right)$, with unclothed carcasses decomposing faster than clothed carcasses. However, the overall decomposition rates from each carcass group are too similar to separate when applying a $95 \% \mathrm{Cl}$, which means that, although statistically significant, from a practical forensic point of view they are not sufficiently dissimilar as to warrant the application of different formulae to estimate the post mortem interval. Further results demonstrated clothing provided Diptera species with additional colonization locations.

Keywords

Forensic Science, Forensic Anthropology, taphonomy, decomposition, clothing, insect colonization

Running Title: Clothing, Decomposition Rate and Diptera Colonization 
Despite the presence of partial or completely clothed individuals in forensic casework (1-3), very little experimental research has been directed towards evaluating the impact of clothing on the rate and pattern of decomposition. Furthermore, as insect activity has been shown to be one of the main factors that affects the rate of decomposition (4-8), it is equally as important to quantitatively examine how clothing may impact insect colonization and development. Several retrospective studies $(1,9)$ and case reports $(10,11)$ have claimed that clothing retards the rate of decomposition because it both prevents insects from accessing desirable locations for oviposition on a corpse and helps to protect decomposing tissue from external factors (e.g. sunlight or scavenging) that might affect the rate of decomposition. Conversely, other experimental studies $(12,13)$ noted accelerations in the rate of decomposition proposing that because clothing creates new areas for insect oviposition and reduces tissue desiccation, these conditions promote feeding for colonizing insects. Lastly, research has suggested either that clothing has no quantitative effect on the rate of decomposition $(14,15)$ or that there is a seasonal interaction with clothing affecting decomposition; Miller (16) reported a difference in the rate of decomposition during summer months, but no difference in rate for winter months in clothed bodies. Furthermore, research into the pattern of regional decomposition of human cadavers has shown that areas of the body with natural orifices and more soft tissue (i.e. torso and head/neck) are among the fastest to decompose whereas those with more collagen and less soft tissue (i.e. limbs) are among the slowest (17). As such, this research was to determine (a) whether the presence of clothing significantly affected the rate of decomposition and Diptera colonization and (b) whether clothed remains decomposed in a different pattern when compared to unclothed remains.

\section{Materials and Methods}

After ethical approval was obtained from the University of Central Lancashire's (UCLan) Animal Projects Committee, 20 Sus scrofa carcasses were killed by captive bolt gun. The carcasses were immediately bagged to prevent early insect access, and then transported to UCLan's Taphonomic 
Research in Anthropology: Centre for Experimental Studies (TRACES) facility; 13 acres of rough pasture with lightly forested borders, located in North West England. Average daily temperatures during the experimental period (May 29, 2012 to July 25, 2012) were recorded to calculate ADD.

Each carcass was weighed using a hanging scale, to the nearest $50 \mathrm{~g}$. The weight of carcasses ranged from $20.90 \mathrm{~kg}$ to $38.50 \mathrm{~kg}$. An electronic USB data logger was inserted rectally to record internal carcass temperature throughout the duration of the experiment. Carcasses were randomly separated into two treatment groups. Ten carcasses comprised the unclothed control group, which were deposited on the ground surface without being dressed while the remaining 10 carcasses represented the clothed treatment group. These carcasses were each dressed in identical white cotton t-shirts, black cotton boxer shorts and belts before being deposited onto the research field (Figure 1). The clothing chosen was meant to mimic loose-fitting, summer clothing. Due to the difference in pig versus human body proportions the t-shirts covered the majority of the carcasses' forelimbs while the shorts left more of the hind limbs and genital areas exposed. All carcasses were placed between 5 to 7 meters apart. Wire mesh cages were placed over carcasses to prevent vertebrate scavengers from accessing the decomposing remains as per TRACES biosafety protocols. Data collection occurred every other day for the first month of the study. When the decomposition rate appeared to slow, data collection intervals increased to every four days. Data collection began in the morning (between 8:00am and 9:00am) of each sampling day and finished by early afternoon (between 12:00pm and 1:00pm). Carcasses were photographed and the head/neck, thorax and limbs were all scored separately, then combined to determine TBS $_{\text {surf }}$ according to the Megyesi et al. (18) method. The location of various insects and/or eggs was noted, though insects other than Diptera species were not the focus for this project. Samples of third instar maggots were collected from randomly selected carcasses within each treatment group once a week. After collection, maggot samples were transported to the entomology lab located at UCLan to be reared to adulthood in containers with pig liver. 


\section{Statistical Analysis}

A Shapiro-Wilks test of normality was used to determine if carcass weights were normally distributed and a t-test was used to compare the weights of carcasses in the two treatment groups. A mixed-effects linear model was used in order to determine if clothing had a significant effect on the overall rate; measured as decomposition level (TBS surf $_{\text {over time }}(\mathrm{ADD})$. $\mathrm{TBS}_{\text {surf }}$ served as the dependent variable; ADD and treatment served as the independent variables. Because each pig was scored at each observation period, the model was effectively one of repeated-measures, with 'pig' as the random variable. The ADD variable was transformed to base $10 \log (\log 10 A D D)$ as it provided a better fit for the data. A similar approach was also used to for the regional analyses of the carcass, regions as defined by Megyesi et al. (18). ANOVA was used to determine if there was a significant difference in ADD of first appearance for identified Diptera species. Statistical analyses for this project were carried out using the statistical package $\mathrm{R}$ (version 2.12.1)(19).

\section{Results and Discussion}

Table 1 displays average daily temperatures throughout the experimental period. No significant differences in carcass weight were found between the two groups, $\mathrm{t}_{18}=0.25, \mathrm{p}=0.809$ (degrees of freedom given in subscript). Unclothed carcasses decomposed faster than clothed carcasses, $t_{427}=2.59, p=0.010$. Formulae for regression lines revealed slopes of similar values for both treatment groups; TBS $=-38.71(\log 10 A D D)+24.19$ for unclothed remains and TBS $=-37.60(\log 10 A D D)+23.23$ for clothed remains. In order to determine the forensic practicality of this statistical finding, a $95 \%$ confidence interval $(\mathrm{Cl})$ was plotted on the data, Figure 2. In forensic practice, it is generally accepted that supporting conclusions with a $95 \% \mathrm{Cl}$ provide a suitable framework from which to base anthropological estimations $(20,21)$. When these error margins are applied to the above data (Figure 2), the overall decomposition rate between the two carcass groups cannot be effectively separated due to a high degree of overlap. This finding supports the more recent research which also found no difference in decomposition rate between unclothed and clothed remains $(14,15)$. This 
result is likely due to the fact that the clothing, although covering much of the carcass, left common areas for insect oviposition unobstructed. The nose, mouth, anus and genital areas were all relatively accessible and, based on location of egg clusters and maggot masses, it appears that insects exploited these areas for colonization.

Although the relative load of Diptera larvae appeared similar within both carcass groups, there appeared to be qualitatively larger concentrations of eggs and maggot larvae in the pelvic, neck and 'armpit' areas on the clothed carcasses compared to the unclothed. Egg clusters and maggot larvae were found in areas of the eyes, mouth and genitals for both groups but additional egg and larvae clusters were found in clothing folds and along the waistband and collar. Three Diptera species were identified after rearing: Calliphora vicina Robineau-Desvoidy, Calliphora vomitoria (Linnaeus), and Protophormia terraenovae (Robineau-Desvoidy). Each of these species was found to be present on both unclothed and clothed carcasses. No significant difference was found in the ADD of first appearance for each species between the groups, $\left(F_{1,4}=0.06, p=0.814\right)$. Thus, earlier research reporting that clothed remains provide additional areas for oviposition (2) is supported by these findings. The same species of Diptera were found on both carcass groups and ADD of first appearance was not found to be statistically significant. These results indicate that within this experimental environment the same types of insects were equally as attracted to clothed remains as they were to unclothed remains. This result may be dependent on the ecology at TRACES, as varying climates are host to different species of insects.

Both the clothed and unclothed carcasses decomposed in a different pattern to what has previously been reported in the literature in regards to regional body decomposition. Within both carcass groups the head/neck region decomposed the fastest compared to limbs and torso (unclothed: $\mathrm{t}_{1299}=13.28, \mathrm{p}<0.001$; clothed: $\left.\mathrm{t}_{1299}=10.67, \mathrm{p}<0.001\right)$. The limbs, however, decomposed significantly faster than the torso (unclothed: $\mathrm{t}_{1299}=2.57, \mathrm{p}=0.010$; clothed: $\mathrm{t}_{1299}=3.41, \mathrm{p}=0.007$ ). This contradicts previous work which claimed soft tissue areas with higher amounts of collagen and skeletal muscles 
would be among the slowest to decompose (17). These characteristics of relative tissue distribution are displayed by limbs of both pigs and humans. Therefore, it would be beneficial for forensic anthropologists to note if this acceleration in limb decomposition in pig carcasses is a common occurrence as it could be helpful for understanding and interpreting any minor pattern differences observed between human and non-human decomposition.

\section{Conclusions}

In terms of forensic relevance, it appears that light weight clothing has no practical effect on PMI estimation for decomposing Sus scrofa remains. Clothing did, however, provide colonizing insects with new areas for oviposition which resulted in differing localized patterns of decomposition between unclothed and clothed carcasses. Although providing more places for colonization, the presence of clothing did not lead to earlier appearances of Diptera species.

\section{Acknowledgements}

The authors would like to thank Duncan Greeley for help with pig supply, Adam Wilcox for help with set up as well as UCLan's 2011-2012 Msc. Forensic Anthropology cohort for all of their support and assistance throughout this experiment. The authors would also like to acknowledge and thank the anonymous peer reviewers for their helpful comments concerning the previous versions of this manuscript. 


\section{References}

1 Komar, DA. Decay Rates in a Cold Climate Region: A Review of Cases Involving Advanced Decomposition from the Medical Examiner's Office in Edmonton, Alberta. J Forensic Sci 1998 Jan;43(1):57-61.

2 Dillon, L., Anderson, GS. Forensic Entomology: The Use of Insects in Death Investigations to Determine Elapsed Time Since Death. Canadian Police Research Centre; 1995 Report No.: TR-05-95.

3 Dillon, L, Anderson, GS. Forensic Entomology: The Use of Insects in Death Investigations to Determine Elapsed Time Since Death in Interior and Northern British Columbia Regions. Canadian Police Research Centre; 1996 Report No.: TR-03-96.

4 Hewadikaram, KA, Goff, ML. Effect of Carcass Size on Rate of Decomposition and Arthropod Succession Patterns. Am J Forensic Med Pathol 1991 Sep;12(3):235-240.

5 Simmons, T, Adlam, RE, Moffatt, C. Debugging Decomposition Data - Comparative Taphonomic Studies and the Influence of Insects and Carcass Size on Decomposition Rate. J Forensic Sci 2010 Jan;55(1):8-13.

6 Simmons, T., Cross, PA, Adlam, RE, Moffatt, C. The Influence of Insects on Decomposition Rate in Buried and Surface Remains. J Forensic Sci 2010 Jul;55(4):889-892.

7 Mann, RW, Bass, WM, Meadows, L. Time Since Death and Decomposition of the Human Body: Variables and Observations in Case and Experimental Field Studies. J Forensic Sci 1990 Jan;35(1):103-111.

8 Campobasso, CP, Di Vella, G, Introna, F. Factors Affecting Decomposition and Diptera Colonization. Forensic Sci Int 2001 Aug;120(1-2):18-27. 
9 Goff, ML. Problems in Estimation of Postmortem Interval Resulting from Wrapping of the Corpse: A Case Study from Hawaii. J Agric Entomol 1992 Oct;9(4):237-243.

10 Haglund, WD. Dogs and Coyotes: Postmortem Involvement with Human Remains. In: Haglund, WD, Sorg, MH, editors. Forensic Taphonomy: The Postmortem Fate of Human Remains. Florida: CRC Press, 1997;367-381.

11 Manhein, MH. Decomposition Rates of Deliberate Burials: A Case Study of Preservation. In: Haglund, WD, Sorg, MH, editors. Forensic Taphonomy: The Postmortem Fate of Human Remains. Florida: CRC Press, 1997;469-482.

12 Anderson, GS. Factors that Influence Insect Succession on Carrion. In: Byrd, JH, Castner, JL, editors. Forensic Entomology: The Utility of Arthropods in Legal Investigations, 2nd ed. Florida: CRC Press, 2010;201-250.

13 Aturaliya, S, Lukasewycz, A. Experimental Forensic and Bioanthropological Aspects of Soft Tissue Taphonomy: 1. Factors Influencing Postmortem Tissue Desiccation Rate. J Forensic Sci 1999 Sep;44(5):893-6.

14 Dautartas, AM. The Effect of Various Coverings on the Rate of Human Decomposition [thesis]. Knoxville (TN): Univ. of Tennessee, Knoxville, 2009.

15 Kelly, JA. The Influence of Clothing, Wrapping and Physical Trauma on Carcass Decomposition and Arthropod Succession in Central South Africa [thesis]. Bloemfontein (South Africa): University of the Free State, 2006.

16 Miller, RA. The Affects [sic] of Clothing on Human Decomposition: Implications for Estimating Time Since Death [thesis]. Knoxville (TN): University of Tennessee, Knoxville, 2002. 
17 Gill-King, H. Chemical and Ultrastructural Aspects of Decomposition. In: Haglund, WD, Sorg, MH, editors. Forensic Taphonomy: The Postmortem Fate of Human Remains. Florida: CRC Press, 1997;93-108.

18 Megyesi, MS, Nawrocki, SP, Haskell, NH. Using Accumulated Degree-Days to Estimate the Postmortem Interval from Decomposed Human Remains. J Forensic Sci 2005 May;50(3):618626.

19 R Development Core Team. R: A language and environment for statistical computing. $\mathrm{R}$ Foundation for Statistical Computing, Vienna, Austria 2010. ISBN 3-900051-07-0, URL http://www.R-project.org/

20 Giles, E, Klepinger, LL. Confidence Intervals for Estimates Based on Linear Regression in Forensic Anthropology. J Forensic Sci 1988 Sep;33(5):1218-1222.

21 Steadman, DW, Adams, BJ, Konigsberg, LW. Statistical Basis for Positive Identification in Forensic Anthropology. Am J Phys Anthropolo 2006 Sep;131(1):15-26. 
Additional Information and Reprint Requests

Allison Card, MSc., FA Cert-III

School of Forensic and Investigative Sciences

University of Central Lancashire,

PRESTON, PR1 2HE, United Kingdom

Tel: +44 (0) 1772894333

E-mail: ACard1@uclan.ac.uk 